\title{
Jurist-Diction
}

Volume 4 No. 1, Januari 2021

\section{Pidana Pencabutan Hak Dipilih Dalam Jabatan Publik Terhadap Pelaku Tindak Pidana Korupsi Paska Putusan Mahkamah Konstitusi Nomor: 56/PUU-XVII/2019}

\author{
Dicky Mario Pratama \\ dickymario11@gmail.com \\ Universitas Airlangga
}

How to cite:

Dicky Mario Pratama, 'Pidana Pencabutan Hak Dipilih Dalam Jabatan Publik Terhadap Pelaku Tindak Pidana Korupsi Paska Putusan Mahkamah Konstitusi Nomor: 56/PUUXVII/2019' (2021) Vol. 4 No. 1 Jurist-Diction.

Histori artikel:

Submit 09 November 2020; Diterima 09 Desember 2020; Diterbitkan 5 Januari 2021.

DOI:

10.20473/jd.v4i1.24294

p-ISSN: 2721-8392

e-ISSN: $2655-8297$

\section{Abstract}

This article is an a normative legal research using conceptual approach, statute approach, and case approach. Whereas the formulation of the problem which becomes the legal issue in this thesis is regarding the characteristic of criminal revocation of elected rights in public office in corruption and the legal consequences of the Constitutional Court Number: 56/PUU-XVII/ 019 against the imposition of criminal revocation of elected rights in public office in criminalacts of corruption. Characteristics of criminalrevocation of elected rightsinpublic officeis regulated inArticle 18 of Law Number 31 Year 1999 concerning Eradication of Corruption refers to provisions of the Criminal Code and concreted through various court decisions in judexfactie and judex jurist level. MeanwhileConstitutional Court Decision Number: 56/PUU-XVII/2019 reinforces the existence of the additional punishment in the form of revocation of elected rights in public office against corruption actorsand becomes reference to the duration of the revocation of rights for five yearat the same time.

Keywords: Additional Sentences; Corruptions.

\section{Abstrak}

Artikel ini merupakan penelitian hukum normatif dengan menggunakan pendekatan konseptual, peraturan perundangan-undangan dan kasus. Sedangkan rumusan masalah yang menjadi isu hukum dalam skripsi ini adalah mengenai karakteristik pidana pencabutan hak dipilih dalam jabatan publik dalam tindak pidana korupsi dan akibat hukum Putusan Mahkamah Konstitusi Nomor: 56/PUU-XVII/2019 terhadap penjatuhan pidana pencabutan hak dipilih dalam jabatan publik dalam tindak pidana korupsi. Karakteristik pidana pencabutan hak dipilih dalam jabatan publik yang dimaksud berupa pidana tambahan yang diatur oleh Pasal 18 UU Nomor 31 Tahun 1999 Tentang Pemberantasan Tindak Pidana Korupsi dengan merujuk pada ketentuan-ketentuan KUHP selanjutnya dikonkritisai melalui berbagai putusan pengadilan ditingkat judex factie dan judex jurist. Sementara itu, Putusan Mahkamah Konstitusi Nomor: 56/PUU-XVII/2019 mempertegas eksistensi penjatuhan pidana tambahan berupa pencabutan hak dipilih dalam jabatan publik terhadap pelaku tindak pidana korupsi serta sekaligus menjadi rujukan mengenai lamanya pencabutan hak yakni selama lima tahun.

Kata Kunci: Pidana Tambahan; Tindak Pidana Korupsi.

Copyright (C) 2021 Universitas Airlangga 


\section{Pendahuluan}

Pidana tambahan berupa pencabutan hak dipilih dalam jabatan publikterhadap pelaku tindak pidana korupsi merujuk kepada ketentuan Pasal 18 Ayat (1) huruf d Undang-Undang Nomor 31 Tahun 1999 tentang Pemberantasan Tindak Pidana Korupsi sebagaimana telah diubah melalui Undang-Undang Nomor 20 Tahun 2001 tentang Perubahan Atas Undang-Undang Nomor 31 Tahun 1999 tentang Pemberantasan Tindak Pidana Korupsi (selanjutnya disebut UU Pemberantasan Tipikor). Pencabutan seluruh atau sebagian hak-hak tertentu sebagaimana diatur dalam Pasal 18 Ayat (1) huruf d tersebut ditasrikan sebagai pencabutan hak dipilih dalam jabatan publik melalui berbagai putusan pengadilan tindak pidana korupsi misalnya terhadap Irjen Djoko Susilo dalam kasus korupsi pengadaan simulator SIM Korlantas Mabes Polri, Luthfi Hasan Ishak dan seterusnya.

Penjatuhan pidana tambahan berupa pencabutan hak dipilh dalam jabatan publik menghilangkan hak-hak pelaku tindak pidana korupsi untuk dapat mencalonkan diri sebagai pejabat publik termasuk mencalonkan diri untuk menjadi kepala daerah meliputi:Gubernur/Wakil Gubernur, Bupati/Wakil Bupati dan Walikota/Wakil Walikota. Hal tersebut ditegaskan melalui ketentuan Pasal 7 Ayat (2) Undang-Undang Nomor 10 Tahun 2016 tentang Perubahan Kedua Atas Undang-Undang Nomor 1 Tahun 2015 tentang Penetapan Perppu Nomor 1 Tahun 2014 tentang Pemilihan Gubernur, Bupati, dan Walikota menjadi Undang-Undang (selanjutnya dalam penulisan ini disebut dengan UU Pilkada) yang menyatakan bahwa syarat calon kepala daerah adalah tidak pernah sebagai terpidana berdasarkan putusan pengadilan yang telah memperoleh kekuatan hukum tetap atau bagi mantan terpidana telah secara terbuka dan jujur mengemukakan kepada publik bahwa yang bersangkutan mantan terpidana dan tidak sedang dicabut hak pilihnya berdasarkan putusan pengadilan yang telah mempunyai kekuatan hukum tetap.

Ketentuan Pasal 7 ayat (2) huruf g UU Pilkada tersebut dinilai tidak memberikan kepastian hukum dan mendukung semangat pemberantasan korupsi. Indonesian Coruption Watch (ICW)melakukan uji materi (judicial review) terhadap ketentuan Pasal 7 ayat (2) huruf g UU Pilkada tersebut. Mahkamah Konstitusi 
sebagaimana diregister dalam Perkara Nomor 56/PUU-XVII/2019,yang Amar Putusannya berbunyi:

\section{MENGADILI}

Dalam Provisi:

Mengabulkan permohonan provisi para Pemohon untuk seluruhnya

Dalam Pokok Permohonan:

1. Mengabulkan permohonan para Pemohon untuk sebagian;

2. Menyatakan Pasal 7 ayat (2) huruf g Undang-Undang Nomor 10 Tahun 2016 tentang Perubahan Kedua Atas Undang-Undang Nomor 1 Tahun 2015 tentang Penetapan Peraturan Pemerintah Pengganti Undang-Undang Nomor 1 Tahun 2014 tentang Pemilihan Gubernur, Bupati, Dan Walikota Menjadi UndangUndang (Lembaran Negara Republik Indonesia Tahun 2016 Nomor 130, Tambahan Lembaran Negara Republik Indonesia Nomor 5898) bertentangan dengan Undang-Undang Dasar 1945 dan tidak mempunyai kekuatan hukum mengikat secara bersyarat sepanjang tidak dimaknai telah melewati jangka waktu 5 (lima) tahun setelah mantan terpidana selesai menjalani pidana penjara berdasarkan putusan pengadilan yang telah mempunyai kekuatan hukum tetap; sehingga Pasal 7 ayat (2) huruf g Undang-Undang Nomor 10 Tahun 2016 tentang Perubahan Kedua Atas Undang-Undang Nomor 1 Tahun 2015 tentang Penetapan Peraturan Pemerintah Pengganti Undang-Undang Nomor 1 Tahun 2014 tentang Pemilihan Gubernur, Bupati, Dan Walikota Menjadi Undang-Undang (Lembaran Negara Republik Indonesia Tahun 2016 Nomor 130, Tambahan Lembaran Negara Republik Indonesia Nomor 5898) selengkapnya berbunyi:

Calon Gubernur dan Calon Wakil Gubernur, Calon Bupati dan Calon Wakil Bupati, serta Calon Walikota dan Calon Wakil Walikota sebagaimana dimaksud pada ayat (1) harus memenuhi persyaratan sebagai berikut:

a. (i) tidak pernah sebagai terpidana berdasarkan putusan pengadilan yang telah memperoleh kekuatan hukum tetap karena melakukan tindak pidana yang diancam dengan pidana penjara 5 (lima) tahun atau lebih, kecuali terhadap terpidana yang melakukan tindak pidana kealpaan dan tindak pidana politik dalam pengertian suatu perbuatan yang dinyatakan sebagai tindak pidana dalam hukum positif hanya karena pelakunya mempunyai pandangan politik yang berbeda dengan rezim yang sedang berkuasa; (ii) bagi mantan terpidana, telah melewati jangka waktu 5 (lima) tahun setelah mantan terpidana selesai menjalani pidana penjara berdasarkan putusan pengadilan yang telah mempunyai kekuatan hukum tetap dan secara jujur atau terbuka mengumumkan mengenai latar belakang jati dirinya sebagai mantan terpidana; dan (iii) bukan sebagai pelaku kejahatan yang berulan-gulang;

3. Menolak permohonan para Pemohon untuk selain dan selebihnya. 
Putusan Mahkamah Konstitusi Nomor 56/PUU-XVII/2019 tersebut di atas membentuk konstruksi hukum baru terhadap syarat pencalonan kepala daerah. Kepala daerah yang telah dinyatakan terbuktimelakukan tindak pidana korupsi dan dijatuhi pidana pokok dengan disertai pidana pencabutan hak dipilih dalam jabatan publik tidak dapat mengajukan sebagai calon kepala daerah selama 5 (lima) tahun setelah selesai menjalankan pidana pokok tersebut. Konsekuensinya, Putusan Mahkamah Konstitusi Nomor 56/PUU-XVII/2019 memiliki dampak terhadap eksistensi penjatuhan pidana pencabutan hak dipilih dalam tidak pidana korupsi.

\section{Karakteristik Pidana Pencabutan Hakdipilih dalam Jabatan Publik Dalam Tindak Pidana Korupsi}

Konstruksi hukum pidana pencabutan hak dipilih dalam jabatan publik tidak dapat dipisahkan dari konstruksi pidana pokok dan pidana tambahan.Secara etimologi, pidana pokok terdiri dari kata "pidana" dan "pokok". Pidana memiliki padanan kata straftyang apabila diartikan menjadi hukuman atau pengenaan nestapa. ${ }^{1}$ Sementara itu, kata "pokok"memiliki diartikan sebagai sesuatu hal yang terutama. ${ }^{2}$ Dengan demikian, pidana pokok dapat diartikan sebagai pemberian nestapa yang terutama. Sementara itu, kata "tambahan" merupakan kata imbuhan yang berasal dari kata "tambah". Dalam bentuk aktif, kata "tambah" menjadi kata "menambah" yang artinya perbuatan membubuhkan sesuatu yang sudah ada sebelumnya supaya yang sudah ada tersebut menjadi lebih banyak atau menjadi lebih besar. ${ }^{3}$

Mengacu kepada pengertian etimologi pidana pokok dan pidana tambahan tersebut di atas dapat dipahami bahwa pidana tambahan tidak dapat berdiri sendiri. Pidana tambahan hanya dapat dijatuhkan setelah adanya pidana pokok.Selain itu, pidana tambahan juga bersifat fakultatif yakni boleh dijatuhkan bolehh tidak. Hal tersebut berkesesuaian dengan pendapat ahli hukum pidana Tolib Setiady. Menurut

\footnotetext{
1 R. Soesilo.. Kitab Undang-Undang Hukum Pidana (KUHP) Serta Komentar-Komentarnya Lengkap Pasal Demi Pasal (Politea 1988).[35].

2 https://kbbi.web.id/pokok, diakses tanggal 10 Februari 2020.

3 ibid.
} 
Tolib Setiady, terdapat perbedaan mendasar antara pidana pokok dengan pidana tambahan. Pidana tambahan hanya dapat ditambahkan kepada pidana pokok, namun dikecualikan terhadap pidana perampasan barang-barang tertentu dan pidana tambahan terhadap anak-anak yang diserahkan kepada pemerintah. ${ }^{4}$ Hal tersebut dikarenakan pidana tambahan yang dikenakan bukanlah suatu pidana melainkan pada tindakan. Sementara itu yang membedakan pidana tambahan lainnya adalah pidana tambahan tidak mempunyai keharusan sebagaimana halnya pidana pokok. Dalam hal ini, sifat dari pidana tambahan ini adalah fakultatif yakni artinya majelis hakim memiliki kebebasan unutk menjatuhkan pidana tambahan atau tidak menjatuhkan pidana tambahan, dikecualikan terhadap kejahatan sebagaimana tersebut tersebut dalam ketentuan Pasal 250 bis, 261 dan Pasal 275 KUHP menjadi bersifat imperatif atau keharusan. ${ }^{5}$

Secara yuridis, konstruksi pidana pokok dan pidana tambahan merujuk kepada Pasal 10 Kitab Undang-Undang Hukum Pidana (KUHP) yang menyatakan pidana pokok terdiri dari Pidana mati, Pidana penjara, Pidana denda dan pidana tutupan. Sementara itu pidana Pidana Tambahan terdiri dari:

1. Pencabutan hak-hak tertentu;

2. Perampasan barang-barang tertentu;

3. Pengumuman putusan hakim.

Merujuk kepada jenis-jenis pidana tambahan tersebut di atas maka pidana pencabutan hak dipilih dalam jabatan publik merupakan salah satu bentuk pidana tambahan berupa pencabutan hak-hak tertentu. Frasa "hak-hak tertentu" sebagai salah satu jenis pidana tambahan memiliki batasan-batasan mengenai hak-hak yang dapat dicabut. Secara filosofis, tidak semua hak yang dapat dicabut karena apabila semua hak tersebut dicabut maka seseorang tersebut akan mati. ${ }^{6}$ Hak-hak teretentu yang dimaksud adalah hak-hak yang telah diatur dan ditegaskan oleh undangundang untuk dapat dicabut berdasarkan putusan pengadilan.

\footnotetext{
${ }^{4}$ Tolib Setiady. Pokok-Pokok Hukum Penitensier Indonesia (Alfabeta 2010).[77].

5 ibid.

${ }^{6}$ R. Soesilo. Op Cit.[55].
} 
Selain pengaturan pidana pokok dan pidana tambahan dijelaskan di atas, pidana pokok dan pidana tambahan juga diatur di luar KUHP. Undang-Undang Nomor 31 Tahun 1999 tentang Pemberantasan Tindak Pidana Korupsi sebagaimana diubah dengan Undang-Undang Nomor 20 Tahun 2001 tentang Perubahan Atas Undang-Undang Nomor 31 Tahun 1999 tentang Pemberantasan Tindak Pidana Korupsi (selanjutnya dalam penulisan akan disebut UU Tipikor) merupakan undang-undang yang secara khususta mengatur tentang pidana pokok dan pidana tambahan terhadap pelaku tindak pidana korupsi.

Ketentuan mengenani pidana pokok terhadap pelaku tindak pidana korupsi diatur dalam Pasal 2 s/d 17 dan Pasal 20. Sedangkan ketentuan mengenai pidana tambahand diatur dalam Pasal 18 dan 19 UU Pemberantasan Tipikor. Jenis-jenis pidana tambahan di luar KUHP sebagaimana diatur dalam Pasal 18 Ayat (1) UU Pemberantasn Tipikor adalah sebagai berikut:

1. Perampasan barang bergerak yang berwujud atau yang tidak berwujud atau barang tidak bergerak yang digunakan untuk atau yang diperoleh dari tindak pidana korupsi, termasuk perusahaan milik terpidana di mana tindak pidana korupsi dilakukan, begitu pula dari barang yang mengantikan barang-barang tersebut;

2. pembayaran uang pengganti yang jumlahnya sebanyak-banyaknya sama dengan harta benda yang diperoleh dari tindak pidana korups;

3. Penutupan Seluruh atau sebagian perusahaan untuk waktu paling lama 1 (satu) tahun;

4. Pencabutan seluruh atau sebagian hak-hak tertentu atau penghapusan seluruh atau sebagian keuntungan tertentu, yang telah atau dapat diberikan oleh Pemerintah kepada terpidana.

Secara yuridis, pidana pencabutan hak dipilih dalam jabatan publik merupakan bagian dari ketentuan pasal 18 Ayat (1) yang menyatakan pencabutan seluruh atau sebagaian hak-hak tertentu. Meskipun frasa "pencabutan seluruh atau sebagian hak-hak tertentu" tidak menjelaskan secara eksplisit mengenai jenis hak yang akan dicabut dan apakah termasuk hak dipilih dalam jabatan publik akan tetapi berbagai putusan pengadilan telah memberikan penafsiran bahwa bahwa hak-hak tertentu yang dimaksud tersebut termasuk pencabutan hak dipilih dalam jabatan publik.

Secara faktual, putusan pengadilan yang pertama kali menjatuhkan pidana pencabutan hak dipilih dalam jabatan publik pertama kali adalah dalam perkara kasus 
korupsi dengan Terdakwa Djoko Susilo. Pengadilan Tinggi Jakarta melalui Putusan Nomor 36/PID/TPK/2013/PT.DKI, Tanggal 18 Desember 2013 mengkoreksi putusan Pengadilan Tindak Pidana Korupsi Pada Pengadilan Negeri Jakarta Pusat Nomor 20/PID.SUS/TPK/2013/PN JKT PST Tanggal 3 Sepetember 2012 dengan menghukum Terdakwa Djoko Susilo dengan pidana tambahan berupa pencabutan hak-hak tertentu untuk memilih dan dipilih dalam jabatan publik.

Dalam tingkat judex juris, Mahkamah Agung dalamputusanNomor 537/K/ Pid.Sus/2014 a.n Terdakwa Djoko Susilo menguatkan putusan Pengadilan Tindak Pidana Korupsi Pada Pengadilan Negeri Jakarta Pusat Nomor 20/PID.SUS/ TPK/2013/PN JKT PST mengenai penjatuhan pidana pencabutan hak dipilih dalam jabatan publik. Selanjutnya, putusan Mahkamah Agung Nomor 537/K/Pid. Sus/2014 tersebut menjadi landmark decision bagi pengadilan selanjutnya dalam menjatuhkan pidana tambahan berupa pencabutan hak dipilih dalam jabatan publik, diantaranya Putusan Mahkamah Agung dalam perkara Nomor: 1995K/Pid.Sus/2014 a.n Terpidana Hasan Luthfi Ishaaq.

Merujuk kepada Putusan Mahakamah Agung dalam Putusan Nomor 537/K/ Pid.Sus/2014 a.n Terdakwa Djoko Susilo dan Putusan Mahkamah Agung dalam perkara Nomor: 1995K/Pid.Sus/2014 a.n Terpidana Luthfi Hasan Ishaaq, dapat ditarik kesamaan bahwa masing-masing Terdakwa selain didawak dengan tindak pidana korupsi yang diatur dalam Undang-Undang Nomor 31 Tahun 1999 tentang Pemberantasan Tindak Pidana Korupsi sebagaimana diubah dengan UndangUndang Nomor 20 Tahun 2001 tentang Perubahan Atas Undang-Undang Nomor 31 Tahun 1999 tentang Pemberantasan Tindak Pidana Korupsi (selanjutnya dalam penulisan akan disebut UU Pemberantasan Tipikor), juga didakwa dengan tindak pidana pencucian uang sebagaiamana diatur dalam Undang-Undang Nomor 8 Tahun 2010 Tentang Pencegahan dan Pemberantasan Tindak Pidana Pencucian Uang.

Masing-masing dalam putusan, Terdakwa Djoko Susilo dan Lutfhi Hasan Ishaq dinyatakan terbukti menerima sejumlah uang atas tindak pidana korupsi yang telah dilakukan. Terdakwa Djoko Susilo dinyatakan telah menerima sebesar Rp54 milyar uang dari pengadaan simulator Surat Izin Mengemudi di Korlantas. 
Sementara itu Lutfhi Hasan Ishaq terbukti telah menerima janji pemberian uang Rp40.000.000.000,00 (empat puluh miliar rupiah) yang sebagian dari padanya yaitu sebesar Rp1.300.000.000,00 (satu miliar tiga ratus juta rupiah) telah diterima melalui saksi Ahmad Fathanah, saksi Maria Elizabeth Liman tidak akan memberikan uang tersebut tanpa keterlibatan terdakwa untuk membantunya. Atas penerimaan sejumlah uang tersebut, Terdakwa Djoko Susilo dan Lutfhi Hasan Ishaq dinyatakan telah terbukti melakukan tindak pidana pencucian uang.

Mengenai penjatuhan pidana tambahan berupa pencabutan hak dipilih dalam jabatan publik dapat menelaah tuntutan Jaksa Penutut Umum yang dibenarkan oleh Majelis Hakim. Dalam perkara Terdakwa Luthfi Hasan Ishaaq, pertimbangan Jaksa Penuntut Umum adalah sebagai berikut:

“......karena penjatuhan pidana tambahan berupa pencabutan hak Terdakwa untuk dipilih sebagai wakil rakyat dan hak untuk menjabat sebagai pengurus suatu partai politik sangatlah dimungkinkan berdasarkan ketentuan Pasal 18 ayat (1) hurufd Undang-Undang Nomor 31 Tahun 1999 tentang Pemberantasan Tindak Pidana Korupsi sebagaimana telah diubah dengan Undang-Undang Nomor 20 Tahun 2001 tentang Perubahan Atas Undang-Undang Nomor 31 Tahun 1999 tentang Pemberantasan Tindak Pidana Korupsi jo Pasal 10 huruf b angka 1 KUHPidana."

Hal ini dimaksudkan agar seseorang yang telah di vonis bersalah melakukan tindak pidana Korupsi dan tindak pidana Pencucian Uang tidak lagi diberi kesempatan untuk memegang jabatan publik yang rentan terhadap perbuatan Korupsi, Kolusi dan Nepotisme (KKN), sehingga dengan penjatuhan pidana tambahan dapat menimbulkan efek jera bagi pelaku tindak pidana Korupsi dan tindak pidana Pencucian Uang. Ada beberapa contoh kasus di Komisi Pemberantasan Korupsi (KPK), di mana pelaku yang telah di vonis bersalah melakukan tindak pidana Korupsi, namun setelah ke luar dari penjara, tetap memegang jabatan publik seperti menjadi Bupati dan sebagainya. Hal ini sungguh sangat mencederai rasa keadilan masyarakat.

Lebih lanjut, Majelis Hakim di tingkat Kasasi menguraikan ratio decidendi penjatuhan pidana pencabutan hak dipilih dalam jabatan publik dengan argumentasi hukum sebagai berikut: 
1. Di persidangan, Terdakwa Lutfhi Hasan Ishak telahdinyatakan terbukti bersalah melakukan tindak pidana Pencucian Uang yang diatur dalam Pasal 3 Ayat (1) a, b, c, Pasal 6 Ayat (1) a, b, c Undang-Undang No.15 Tahun 2002 joUndangUndang No.25 Tahun 2003, Pasal 3 dan Pasal 5 Undang-Undang No.8 Tahun 2010

2. Penjatuhan pidana tambahan berupa pencabutan hak untuk dipilih dalam jabatan publik terhadap Luthfi Hasan Ishaq dikarenakan Luthfi Hasan Ishaq terbukti melakukan gabungan beberapa perbuatan sebagaimana yang diatur dalam Pasal 65 ayat (1) KUHP dan penjatuhan pidana pencabutan hak untuk dipilih dalam jabatan publik tersebut juga bertujuan untuk mewujudkan rasa keadilan yang hidup dalam masyarakat sebagaimana diatur dalam Pasal 10 KUHP;

3. Terdapat hal-hal yang memberatkan Terdakwa Luthfi Hasan Ishak sebagaimana dimaksud dalam Pasal 197 ayat (1) f KUHAP, hal-hal yang memberatkan tersebut diantaranya Terdakwa Lutfhi Hasan Ishaq melakukan perbuatan korupsi sewaktu menajabat sebagai anggota DPR RI. Dimana, selaku anggota DPR telah melakukan hubungan transaksional dengan mempergunakan kekuasaan elektoral demi untuk mendapatkan imbalan. Hal tersebut terbukti dengan Terdakwa Lutfhi Hasan Ishaaq telah menerima janji pemberian uang Rp40.000.000.000,00 (empat puluh miliar rupiah) yang sebagian dari padanya yaitu sebesar Rp1.300.000.000,00 (satu miliar tiga ratus juta rupiah) telah diterima melalui saksi Ahmad Fathanah, saksi Maria Elizabeth Liman tidak akan memberikan uang tersebut tanpa keterlibatan terdakwa untuk membantunya.

Pertimbangan tersebut sangat berkesesuaian dengan tujuan pembentukan undang-undang pemberantasan tindak pidana korupsi. Tujuan dibuatnya hukum acara tindak pidana korupsi yang menyimpang dari pidana umum yakni menekan seminimal mungkin terjadinya kebocoran serta penyimpangan terhadap keuangan dan perkeonomian negara. ${ }^{7}$

\footnotetext{
7 Lilik Mulyadi. Pembalikan Beban Pembuktian. (PT Alumni 2007).[3].
} 
Merujuk kepada Putusan kepada Putusan Mahakamah Agung dalam Putusan Nomor 537/K/Pid.Sus/2014 a.n Terdakwa Djoko Susilo dan Putusan Mahkamah Agung dalam perkara Nomor: 1995K/Pid.Sus/2014 a.n Terpidana Luthfi Hasan Ishaaq maka kualifikasi penjatuhan pidana pencabutan hak dipilih dalam jabatan publik didasarkan rangkaian tindak pidana yang dilakukan oleh terdakwa dan kondisi pelaku tindak pidana korupsi. Rangkaian tindak pidana korupsi yang dimaksud adalah tindak pidana korupsi yang dilakukan oleh terdakwa dibuktikan dengan adanya aliran sejumlah uang atau sejumlah keuntungan kepada terdakwa. Selanjutnya, terdakwa juga terbukti mengabulkan asal-usul uang atau keuntungan dari hasil tindak pidana korupsi tersebut. Di persidangan aliran uang hasil korupsi dan tindak pidana pencucian uang mengacu pada alat-alat bukti yang digunakan untuk membuktikan telah terjadinya suatu peristiwa hukum atau disebut bewijijsmidden yakni tindak pidana korupsi dan tindak pidana pencucian uang. ${ }^{8}$

Adapun kondisi pelaku yang dimaksud adalah pelaku saat melakukan tindak pidana korupsi merupakan pejabat publik. Adapun pejabat publik yang dimaksud adalah mereka yang mengemban jabatan publik tersebut adalah suatu jabatan legislatif, eksekutif, administratif atau yudisial dari satu negara peserta, ditunjuk atau dipilih, tetap atau sementara, dibayar atau tidak dibayar, terlepas dari senioritas orang itu. ${ }^{9}$ Selanjutnya yang berkaitan dengan kondisi pelaku adalah sejalan dengan tujuan penjatuhan pidana sebagai upaya preventif menanggulaingi tindak pidana. Upaya preventif yang dimaksud adalah penjatuhan pidana pencabutan hak dipilih dalam jabatan publik bertujuan untuk mencegah mantan nara pidana pelaku tindak pidana korupsi menduduki kembali jabatan publik yang berpotensi menciptakan rezim korup dan melakukan tindak pidana korupsi (resedivis). ${ }^{10}$

\footnotetext{
8 Edddy O.S. Hiarej. Teori \& Hukum Pembuktian. (Erlangga 2012).[17].

9 Lampiran Pasal 2 huruf a UU No. 7 Tahun 2006 tentang Pengesahan United Nations Convention Against Corruption, 2003 (Konvensi Perserikatan Bangsa-Bangsa Anti Korupsi, 2003) ${ }^{10}$ ibid.[20].
} 


\section{Akibat Hukum Putusan Mahkamah Konstitusi Nomor 56/PUU-XVII/2019 Terhadap Eksistensi Pidana Pencabutan Hak Dipilih Dalam Jabatan Publik}

Putusan Mahkamah Konstitusi Nomor: 56/PUU-XVII/2019 adalah putusan pada tingkat pertama dan terkahir, dimana putusan tersebut bersifat final. Istilah "final" dapat diartikan bahwa putusan Mahkamah Konstitusi langsung memperoleh kekuatan hukum tetap (inkraht van gewijsde)sejak diucapkan. Dengan arti lain, tidak terdapat upaya yang dapat ditempuh untuk mengubah putusan tersebut. Sementara itu, Isitilah "final" memiliki pengertian bahwa Putusan Mahkamah Konstitusi memiliki kekuatan hukum yang mengikat atau binding.Makna mengikat disini adalah putusan Mahkamah Konstitusi memiliki kekuatan mengikat (verbindende kracht) tidak hanya kepada para pihak yang bersengketa melainkan juga berlaku kepada seluruh masyarakat Indonesia.

Putusan Mahkamah Mahkamah Konstitusi Nomor: 56/PUU-XVII/2019yang mengatur tentang masa jeda 5 (lima) tahun bagi terpidana korupsi untuk mencalonkan diri sebagai kepala daerah mengacu kepada putusan Mahkamah sebelumnya pada putusan MK Nomor 71/PUU-XIV/2016. Dalam putusannya, Mahkamah Konstitusi juga pernah memutus Pasal 7 ayat 2 huruf g UU 10 Nomor2016 dan putusan terkait yakni Putusan Mahkamah Konstitusi Nomor: 4/PUU-VII/2009 yang putusannya mengatur tentang norma hukum yang memuat persyaratan tentang pengisian jabatan publik danPutusan Mahkamah Konsitutsi Nomor 120/PUU-VII/2009 tentang negative legislator.

Merujuk kepada Putusan Mahkamah Konstitusi Nomor: 42/PUU-XIII/2015 dan Putusan Mahkamah Konstitusi Nomor 71/PUU-XIV/2016, pandangan Majelish Hakim telah bergeser dari rumusan yang bersifat kumulatif menjadi alternatif. Konsekuensinya, pergeseran pandangan tersebut melonggarkan syarat untuk memperoleh pemimpin yang bersih, jujur dan berintegritas. Lebih lanjut, Majelis Hakim konstitusi berpendapat bahwa demokrasi tidak hanya individu saja, melainkan juga nilai-nilai moralitas seperti kepantasan, kesalehan, kewajara, kemasukakalan, dan keadilan. Selain itu, Majelis Hakim Konstitusi juga menjadikan tradisi di negara-negara barat yang pejabat pemerintahannya mundur tatkala tersandung 
kasus hukum sekalipun pejabat tersebut dipilih rakyat secara langsung. Lebih lanjut, penerapan persyaratan kepada bakal calon kepada daerah secara kumulatif harus diterapkan sesuai dengan norma hukum yang telah dirumuskan oleh Mahkamah Konstitusi sebagaimana dimuat dalam Putusan Mahkamah Konstitusi Nomor: 4/ PUU-VII/2009.

Putusan Mahkamah Konstitusi Nomor: 56/PUU-XVII/2019 yang mengatur yang mengatur tentang masa jeda 5 (lima) tahun bagi terpidana korupsi untuk mencalonkan diri sebagai kepala daerah tersebut menimbulkan konsekuensi yuridis terhadap eksistensipidana pencabutan hak dipilih dalam jabatan publik terhadap pelaku tindak pidana korupsi. Meskipun putusan tersebut hanya mengatur tentang pilkada (bukan undang-undang yang mengatur tentang pemberantasan tipikor dan/ atau UU yang mengatur tentang pidana materil dan formil) akan tetapi putusan teresbut memiliki konsekuensi yuridis terhadap keberlakuan pidana pencabutan hak dipilih dalam jabatan publik dan mekanisme penjatuhan pidana pencabutan hak dipilih dalam jabatan publik dalam penegakan tindak pidana korupsi.

Putusan Mahkamah Konstitusi Nomor: 56/PUU-XVII/2019 dinilai harmonis dengang ketentuan yang ada dalam UU Pemberantasan Korupsi dan Ketentuan Pidana Tambahan dalam KUHP. Putusan Mahkamah Konstitusi Nomor: 56/PUUXVII/2019 juga semakin menegaskan eksistensi penjatuhan pidana tambahan berupa pencabutan hak dipilih dalam jabatan publik. Namun perlu diketahui bahwa terkait dengan pelaksanaan pencabutan hak-hak tertentu dimulai bukan saat hukuman dibacakan melainkan terhitung sejak putusan hakim dapat dilaksanakan. ${ }^{11}$

Dengan demikian, Putusan Mahkamah Konstitusi Nomor: 56/PUU-XVII/2019 dapat menjadi rujukan dan pedoman bagi Jaksa Penuntut Umum dan Majelis Hakim dalam menuntut dan menjatuhkan pidana tambahan berupa pencabutan hak dipilih dalam jabatan publik terhadap terdakwa yang terbutki melakukan tindak pidana korupsi. Penjatuhan pidana pencabutan hak dipilih dalam jabatan publik mengacu kepada hukum acara pidana yang mengatur tata cara penjatuhan pidana pokok.

${ }^{11}$ ibid. [57]. 
Jika penjatuhan pidana tambahan sebagaimana Pasal 10 KUHP mengacu kepada KUHAP maka penjatuhan pidana tambahan berupa pencabutan hak dipilih dalam jabatan publik mengacu kepada KUHAP dan UU Pemberantasan Tindak Pidana Korupsi dan UU Pengadilan Tipikor.

Meskipun terdapat berbagai kekhususan dalam hukum acara pidana korupsi seperti diakomodirnya pembuktian terbalik yang ditujukan terhadap kesalahan orang (Pasal 12 B Ayat (1), Pasal 37 B UU Tipikor) dan kepemilikan harta benda terdakwa (Pasal 37 A, Pasal 38 B UU Tipikor). ${ }^{12}$ Prosedur penjatuhan pidana tambahan berupa pencabutan hak dipilih dalam jabatan publik didasarkan pada proses persidangan. Dakwaan yang disusun dan disampaikan oleh Jaksa Penuntut Umum menjadi dasar pemeriksaan di persidangan. Selanjutnya, fakta-fakta yang diungkapkan dipersidangan menjadi dasar bagi Jaksa Penuntut Umum untuk menyusun surat tuntutan. Begitu juga halnya dengan Majelis Hakim, fakta-fakta di persidangan menjadi dasar untuk menyatakan apakah si Terdakwa telah terbukti secara sah melakukan tindak pidana korupsi sebagaimana di dakwakan.

Setelah mempertimbangkan nota pembelaan yang diajukan oleh Terdakwa maka Majelis Hakim memiliki keharusan untuk membuat pertimbangan hukum (ratio decidendi). Melalui pertimbangan hukum tersebut, hal yang paling utama yang dilakukan oleh Majelis Hakim adalah terkait dengan alat-alat bukti yang digunakan untuk membuktikan telah terjadinya suatu peristiwa hukum atau disebut bewijijsmidden. ${ }^{13}$

Selanjut yang dilakukan majelis hakim adalah membuat pertimbangan terkait dengan tindakan terdakwa apakah telah memenuhi unsur-unsur tindak pidana sebagaimana didakwakan. Unsur-unsur yang dimaksud haruslah merupakan satu kesatuan. Dalam hal salah satu unsur tidak ada atau tidak didukung oleh bukti maka si Terdakwa haruslah dibebaskan dari dakwaan atau tidak dapat dihukum. ${ }^{14}$

Dalam hal perbuatan Terdakwa dinyatakan memenuhi unsur-unsur tindak pidana yang didakwakan, maka Majelis hakim akan mempertimbangkan apakah

\footnotetext{
${ }^{12}$ Lilik Mulyadi,Op.Cit.[11].

${ }^{13}$ Edddy O.S. Hiarej. Teori \& Hukum Pembuktian. (Erlangga 2012).[17].

${ }^{14}$ Leden Marpaung...Unsur-unsur Perbuatan Yang Dapat Dihukum. (Sinar Grafika 1991).[7].
} 
terhadap si Terdakwa dapat dimintakan pertanggungjawaban pidana. Unsur-unsur pertanggungjawaban pidana yang dimaksud meliputi:

1. Hal dapat dipertanggungjawabkannya sesuatu tindakan atau sesuatu akibat terhadap pelakunya;

2. Hal dapat dipertanggungjawabkannya seseorang atas tindakan yang telah ia lakukan atau atas akibat yang telah ia timbulkan;

3. Hal dapat dipersalahkannya sesuatu tindakan atau suatu akibat kepada seseorang oleh karena tindakan atau akibat tersebut telah ia lakukan atau telah ia timbulkan berdassarkan unsur kesengajaan ataupun dengan unsur ketidakengajaan;

4. Sifatnya yang melanggar hukum. ${ }^{15}$

Apabila dinyatakan dapat dimintakan pertanggungjawaban pidana, maka Majelis Hakim mempertimbangkan hal-hal yang memberatkan dan meringankan Terdakwa untuk menentukan jenis dan besaran penjatuhan pidana yakni besaran pidana pokok penjara yang akan dikenakan terhadap si Terdakwa.

Besaran pidana penjara yang akan dijatuhkan kepada Terdakwa menjadi pertimbangan bagi hakim dalam menilai kepantasan dan efektifitas penjatuhan pidana tamabahan berupa pencabutan hak dipilih dalam jabatan publik. Dalam hal Majelis Hakim menilai bahwa terdapat peluang bagi Terdakwa untuk menduduki jabatan publik dan melakukan tindak pidana korupsi di kemudian hari maka penjatuhan pidana tambahan berupa pencabutan hak dipilih dalam jabatan publik dapat dikenakan terhadap si Terdakwa yang bersangkutan.

Lebih lanjut penjatuhan pidana pidana tambahan berupa pencabutan hak dipilih dalam jabatan publik harus dimuat dalam amar putusan. Sedangkan terkait dengan pertimbangan hukum atas penjatuhan pidana tambahan tersebut, majelis hakim wajib memuatnya dalam pertimbangan hukum atau setidak-tidaknya membenarkan pendapat dari Jaksa Penuntut Umum. Selanjutnya putusan tersebut dibacakan dalam sidang yang terbuka untuk umum.

Namun perlu dipahami bahwa penjatuhan pidana tambahan berupa pencabutan hak dipilih dalam jabatan publik, Majelis Hakim harus terikat dengan ketentuan Pasal 38 KUHP yang mensyaratkan lamanya pencabutan hak tertentu ditentukan

15 PAF Lamintang. Dasar-Dasar Hukum Pidana. (PT Citra Aditya Bakti 2011).[197]. 
dengan pidana pokok yang dijatuhkan, yakni:

1. Lamanya pencabutan hak-hak tertentu adalah seumur hidup, apabila terdakwa dikenakan pidana mati atau pidana penjara seumur hidup;

2. Lamanya pencabutan hak-hak tertentu adalah paling sedikit dua tahun dan paling banyak lima tahun lebih lama dari pidana pokoknya, apabila terdakwa dipidana dengan pidana penjara untuk waktu tertentu atau pidan kurungan;

3. Lamanya pencabutan hak-hak tertentu adalah paling sedikit dua tahun dan paling banyak lima tahun, apabila terdakwa dikenakan pidana denda;

4. Pencabutan hak mulai berlaku pada hari putusan hakim dapat dijalankan. ${ }^{16}$

Setelah Putusan Mahkamah Konstitusi Nomor: 56/PUU-XVII/2019 maka amar putusan Majelis Hakim yang memeriksa perkara tindak pidana korupsi harus menegaskan mengenai lamanya pemidanaan pencabutan hak dipilih dalam jabatan publik. Agar putusan pengadilan tersebut harmonis dan tidak tumpang tindih dengan undang-undang maka sebaiknya ditegaskan dalam amar putusan bahwa lamanya pencabutan hak dipilih dalam jabatan publik adalah selama lima tahun.

\section{Kesimpulan}

Pidana pencabutan hak dipilih dalam jabatan publik merupakan pidana tambahan yang diatur oleh Pasal 18 UU Nomor 31 Tahun 1999 Tentang Pemberantasan Tindak Pidana Korupsi dengan merujuk pada ketentuan-ketentuan KUHP selanjutnya dikonkritisai melalui berbagai putusan dalam tingkat judex factie dan judex jurist, dimana penjatuhan pidana pencabutan hak untuk dipilih dalam jabatan publik tersebut merujuk kepada terdakwa yang terbukti melakukan tindak pidana korupsi dan tindak pidana pencucian uang serta kondisi terdakwa yang memungkinkan untuk melakukan kejahatan serupa di kemudian hari. Sementara itu, Putusan Mahkamah Konstitusi Nomor: 56/PUU-XVII/2019 memberikan kepastian hukum terhadap pelaku tindak korupsi untuk menduduki jabatan publik dan sekaligus mempertegas eksistensi penjatuhan pidana tambahan berupa pencabutan hak untuk dipilih dalam jabatan publik terhadap pelaku tindak pidana korupsi serta sekaligus menjadi rujukan mengenai lamanya pencabutan hak yakni selama lima tahun.

${ }^{16}$ ibid. [57]. 


\section{Daftar Bacaan}

\section{Buku}

Adji, Indriyanto Seno, Hukum Pidana Dalam Perkembangan (Diadit Media 2014).

Brugginnk. J. J.. Refleksi Tentang Hukum (Alih Bahasa Sidarta) (PT Citra Aditya Bakti 1999).

Andi Hamzah,. Asas-Asas Hukum Pidana (Rineka Cipta 1994).

Hariyono, dkk. Membangun Negara Hukum Yang Bermartabat (Setara Pers 2013).

Edddy O.S. Hiarej, Teori \& Hukum Pembuktian (Erlangga 2012).

C.S.T. Kansil. Pengantar Ilmu Hukum dan Tata Hukum Indonesia (Balai Pustaka 1989).

Komisi Pemberantasan Korupsi, Memahami Untuk Membasmi, Buku Panduan Untuk Memahami Tindak Pidana Korupsi (KPK 2006)

Peter Mahmud Marzuki, Penelitian Hukum Edisi Revisi (Kencana 2005). , Pengantar Ilmu Hukum (Kencana Pernada Media Group 2008).

Lilik Mulyadi, Pembalikan Beban Pembuktian Tindak Pidana Korupsi, Cetakan II, (Alumni 2013).

PAF Lamintang, Dasar-Dasar Hukum Pidana (PT Citra Aditya Bakti 2011).

R. Soesilo, Kitab Undang-Undang Hukum Pidana (KUHP) Serta KomentarKomentarnya Lengkap Pasal Demi Pasal (Politea) 1988.

Mardjono Reksodiputro, Pembaharuan Hukum Pidana : Kumpulan Karangan Buku Keempat (1999).

Tolib Setiady, Pokok-Pokok Hukum Penitensier Indonesia (Alfabeta 2010).

Soedarto, Kapita Selekta Hukum Pidana (Alumni 1990).

\section{Laman}

Moch. Harun Syah, Kronologi Suap Mantan Presiden PKS Luthfi Hasan (Liputan 6 2013), http://news.liputan6.com/read/621438/kronologi-suap-mantanpresiden-pks-luthfi-hasan. 
Abdul Aziz, Ketika Pencabutan Hak Politik Tidak Mematikan Karier Politisi, (tirto.id 2017), https://tirto.id/ketika-pencabutan-hak-politik-tak-mematikankarier-politisi-cnys,

NN, Anas Urbaningrum Divonis 8 Tahun Penjara, (BBC News Indonesia 2014) https://www.bbc.com/indonesia/berita_indonesia/2014/09/140924_vonis_ anas_urbaningrum. 
Dicky Mario: Pidana Pencabutan Hak...

--halaman ini sengaja dibiarkan kosong-- 